\title{
Content Analysis on Media Online
}

\author{
Prapto Prasojo ${ }^{\mathrm{a}}$, Novrina ${ }^{\mathrm{b}}$ \\ a Prapto.Prasojo@gmail.com \\ ${ }^{a}$ Gunadarma University, Jl. Margonda Raya Pondok Cina, Depok and 16424, Indonesia \\ ${ }^{a}$ Gunadarma University, Jl. Margonda Raya Pondok Cina, Depok and 16424, Indonesia
}

\begin{abstract}
This research discusses the current developments in the use of bitcoin in Indonesia. The data used in content analysis is sourced from three online news media namely detik.com, kompas.com, and liputan6.com. The data collected was 651 news, the data has been processed and verified to ensure there is no duplicate data and is in accordance with bitcoin. The tools used in data retrieval are webharvy version 5.2, then the data is processed using atlas.ti tools version 6.2 to calculate the number of words. From the results of calculations then made (10) ten important concepts, from these concepts the most important concepts are then selected. The concept is the concept of bitcoin, country, platform, value, economy, government, market, company, security, and banking. The method used to conduct this research is qualitative and quantitative. Quantitative methods are used at the time of data collection, while qualitative methods are used to perform data processing and to calculate the connectedness test between each concept using SPSS version 22 tools. The results of the connectedness test are made visually by network connection using tools atlas.ti version 6.2. Based on the visualization, it was found that the economic concept is the most important concept of online news related to bitcoin. The economic concept is connected with the other eight concepts, namely bitcoin, security, country, market, government, banking, companies and platforms.
\end{abstract}

Keywords: Content analysis; Bitcoin; Cryptocurrency; Indonesia

\section{Preliminary}

The emergence of Cryptocurrency today is an innovation in the world of economy. Cryptocurrency is the name given to a system that uses cryptography to carry out the process of sending data securely and to exchange digital tokens in a spread (Dourado \& Brito, 2014). With the concept of cryptocurrency, a digital currency was created by Satoshi Nakamoto (2018) under the name bitcoin. Bitcoin is classified as a crypto currency (cryptocurrency), which is a type of currency in circulation that is not specifically regulated by a particular central bank nor is it regulated by certain countries. Distribution and use through internet network media. Bitcoin itself basically has 2 meanings and views. The first is that bitcoin functions as an independent currency and has no regulatory body. The second is bitcoin as a technology, system, and protocol.

To find out about current information developments, the Indonesian people know a lot through digital media. Many online news portals are presented that are easily accessible to the public. Several online news portals that are well known to the public are detik.com, kompas.com, and also liputan6.com. On the basis of all of the above, this study aims as a means of obtaining important information about bitcoin, and how bitcoin has developed in Indonesia. In this case, the method used to measure bitcoin development is qualitative and quantitative measurements, then with content analysis the words contained in the online news portal will be explained.

This content analysis is carried out by calculating the frequency or number of words that are often expressed on online news portals about bitcoin, and the number of words contained in the news portal are 
combined into one unit based on the similarity of the meaning of the words. The unity of meaning will then be referred to as a concept that will be used and processed by using bivariate connectedness testing to analyze the relationship between one concept and another based on the level of significance.

\section{Literature Review}

\subsection{Content Analysis}

Content analysis is one of the various approaches in research. Content analysis is a research technique to describe clear communication content objectively, systematically, and quantitatively (Berelson, 2009: 97). Content analysis views data not as a collection of events as is common with other methods that view data as a symptom or event as a compound and complex whole, this method views data as symbolic symptoms. This method is more familiar with meanings, references, consequences, and desires that are impossible to achieve with qualitative methods. In practice, content analysis is a quantitative method. Content analysis can be used to analyze all forms of communication, such as movies, books, news, and so on. By using this method, an understanding of the various contents of messages such as online news media will be obtained in an objective, systematic and relevant manner. Content analysis has no potential to show how researchers understand and judge what they see or hear. Content analysis only shows what was given priority or considered important and what was not.

According to Wimmer and Dominick (2000) the objectives of content analysis are:

- Describing communication content (describing communication content).

- Testing the hypothesis of message characteristics.

- Comparing media content with the real world (comparing media content to the "real world").

- Estimating the media's picture of certain groups in society (assessing the image of particular groups in society).

- Supporting mass media effects studies (establishing a starting point for studies of media effects).

- The purpose of content analysis is more focused on the purpose of describing the content of communication and supporting mass media effects studies.

According to Jumal (2018), content analysis research design states that there are strengths and weaknesses between field research and content analysis, namely:

Advantages:

- Save time, effort and cost

- Content analysis is safer to do

- Content analysis allows long-term research

- Content analysis has no social effect because the object is passive Deficiency:

- Has limitations in recording data, and data validity

- There is a lot of information used, so it must be done filtering and carefulness of researchers, especially when coding data

\subsection{Bitcoin}

Bitcoin, the cryptocurrency that is currently the most famous and the most common in the world. Bitcoin was introduced by an unknown person or group in 2009 and released as open source software. The basic concept of bitcoin is to create a decentralized authority transaction system without a third party who can verify using the concept of a digital signature in every transaction (Nakamoto, 2008). By using 
cryptocurrency, users can exchange values digitally without having to worry about being watched by third parties. Bitcoin works on a public ledger technology called blockchain, which holds a decentralized record of all transactions which are updated and held by all network users. Transactions by users are added to blocks which are then converted into complex math. Miners, using high-powered computers, compute this solution which then determines the possible transactions. Apart from that, other miners also check the approved transactions and the miners can get bitcoins. (According to Raghav Gupta, 2017). The image below shows the transaction process and blockchain.

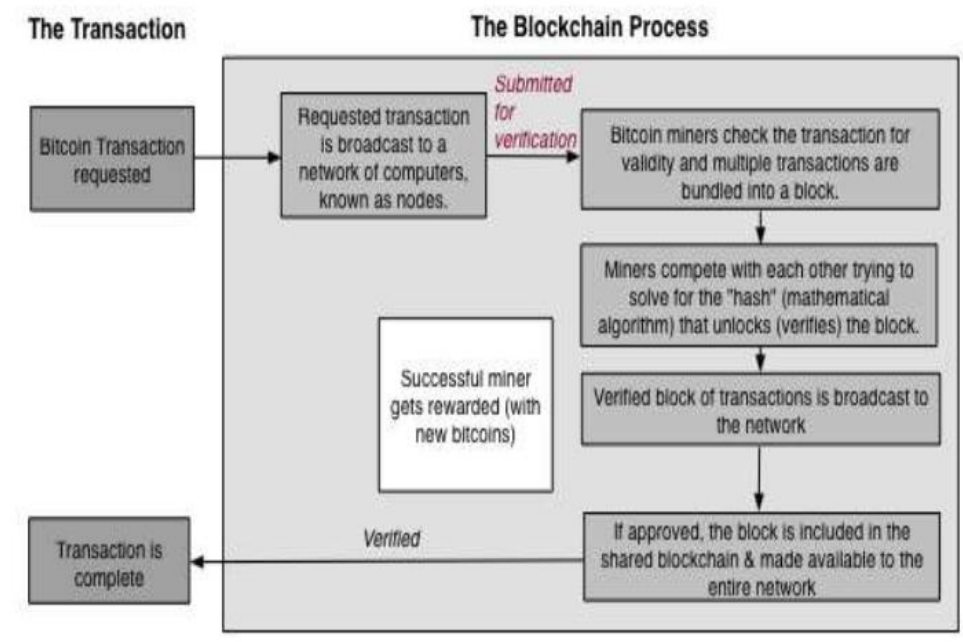

Fig. 1. Transaction Process and Blockchain

According to Bank Indonesia, as the payment system regulator in Indonesia, bitcoins are considered not in accordance with several laws in force in the banking world, namely Law No. 7 of 2011 concerning Currency and Law no. 23 of 1999 concerning Bank Indonesia. In the Currency Law, it is stated that currency is money issued by Bank Indonesia as the central bank, called the rupiah, and in the Bank Indonesia Law, it is stated that the currency that is legally circulating in the Republic of Indonesia is the rupiah currency.

\section{Research Methods}

In this study, two methods were used, namely: quantitative and qualitative methods. The quantitative method was used at the beginning of the research, namely when the news content was collected through three online news portals and from the results of the news content collection, the number of words that often appeared from the news that had been selected would be calculated.

The qualitative method used in this study was used at the data collection stage, namely for data processing. The results of the number of words that often appear will then be followed by the creation of 10 concepts based on the most frequently occurring and relevant words. At this stage, several words that have a connection or relationship between one word and another that have the same meaning with a predetermined concept are also carried out. And at the final stage this method is also used to be carried out at the relationship analysis stage, from these concepts, an analysis of the relationship between one concept will be carried out. 
Fig. 2. Research Framework Chart

\section{Results and Discussion}

A word cruncher is a process that generates a spreadsheet of how often specific words are repeated in one or all main documents. In this process, what will become the primary documents (PD) are 651 news contents obtained from three verified online media websites.

Table 1. Word Cruncher Result

\begin{tabular}{|l|c|c|c|c|c|c|c|c|c|c|}
\hline Words & P 1 & P 2 & P 3 & P 4 & P 5 & P 648 & P 649 & P 650 & P 651 & Total \\
\hline Total: & 244 & 190 & 303 & 382 & 448 & 251 & 339 & 298 & 224 & 198142 \\
\hline BITCOIN & 2 & 3 & 12 & 1 & 7 & 12 & 10 & 1 & 9 & 6572 \\
\hline YANG & 6 & 7 & 9 & 17 & 16 & 11 & 13 & 7 & 4 & 5716 \\
\hline DI & 2 & 7 & 4 & 7 & 6 & 4 & 10 & 5 & 3 & 3594 \\
\hline DAN & 2 & 2 & 7 & 7 & 7 & 2 & 3 & 11 & 3 & 3211 \\
\hline INI & 1 & 2 & 1 & 8 & 7 & 7 & 5 & 3 & 4 & 3120 \\
\hline UANG & 8 & 6 & 0 & 0 & 7 & 3 & 3 & 1 & 1 & 2757 \\
\hline UNTUK & 0 & 3 & 1 & 9 & 5 & 2 & 5 & 8 & 1 & 2118 \\
\hline DENGAN & 2 & 0 & 1 & 8 & 9 & 1 & 6 & 6 & 1 & 2079 \\
\hline DARI & 4 & 3 & 6 & 4 & 11 & 0 & 3 & 1 & 3 & 2023 \\
\hline MATA & 7 & 5 & 0 & 0 & 7 & 2 & 2 & 1 & 1 & 1970 \\
\hline JUGA & 2 & 2 & 3 & 2 & 2 & 2 & 4 & 4 & 2 & 1483 \\
\hline DALAM & 2 & 1 & 1 & 3 & 12 & 3 & 4 & 3 & 1 & 1473 \\
\hline PADA & 1 & 2 & 1 & 0 & 3 & 1 & 3 & 1 & 1 & 1332 \\
\hline ITU & 0 & 3 & 6 & 1 & 2 & 0 & 0 & 1 & 0 & 1304 \\
\hline TIDAK & 5 & 0 & 0 & 2 & 2 & 2 & 1 & 5 & 0 & 1259 \\
\hline TERSEBUT & 0 & 2 & 5 & 0 & 9 & 2 & 0 & 1 & 0 & 1209 \\
\hline AKAN & 1 & 0 & 0 & 3 & 6 & 1 & 6 & 2 & 5 & 1193 \\
\hline DIGITAL & 4 & 0 & 0 & 0 & 6 & 2 & 1 & 2 & 1 & 1177 \\
\hline BISA & 6 & 1 & 2 & 3 & 0 & 1 & 5 & 1 & 0 & 1108 \\
\hline ATAU & 1 & 0 & 1 & 1 & 0 & 1 & 2 & 0 & 1 & 1036 \\
\hline INDONESIA & 0 & 0 & 0 & 2 & 0 & 0 & 0 & 2 & 1 & 990 \\
\hline CRYPTOCURRENCY & 0 & 1 & 1 & 0 & 10 & 0 & 0 & 5 & 0 & 885 \\
\hline
\end{tabular}


After the word cruncher is done, 10 important concepts will be made based on the highest number of words in the content of the news. The concepts are presented in table 2 .

Table 2. Concepts or Code

\begin{tabular}{|c|l|}
\hline No & Concepts or Code \\
\hline 1 & BITCOIN \\
\hline 2 & NEGARA \\
\hline 3 & PLATFORM \\
\hline 4 & NILAI \\
\hline 5 & EKONOMI \\
\hline 6 & PEMERINTAH \\
\hline 7 & PASAR \\
\hline 8 & PERUSAHAAN \\
\hline 9 & KEAMANAN \\
\hline 10 & PERBANKAN \\
\hline
\end{tabular}

After the conceptualization is done, the word is combined with the concept before proceeding to the counting code stage. Counting code is a process for counting all the words that have been combined with the concept.

Table 3. Combining Words with Concepts

\begin{tabular}{|l|l|l|}
\hline No & \multicolumn{1}{|c|}{ Concepts or Code } & \multicolumn{1}{c|}{ Words } \\
\hline 1 & Bitcoin & $\begin{array}{l}\text { Cryptocurrency, Kripto, Blockchain, Ethereum, Btc, Crypto, } \\
\text { Mining }\end{array}$ \\
\hline 2 & Negara & Indonesia, Jakarta \\
\hline 3 & Platform & $\begin{array}{l}\text { Sistem, Digital, Virtual, Teknologi, Komputer, Internet, } \\
\text { Smartphone, Perangkat, Siber, Jaringan, Online, Server }\end{array}$ \\
\hline 4 & Nilai & Rp, Us\$, Usd, Dollar, Miliar, Currency, Rupiah, Triliun \\
\hline 5 & Ekonomi & $\begin{array}{l}\text { Investasi, Pembayaran, Perdagangan, Transaksi, Uang, } \\
\text { Keuangan, Industri, Finansial, Money }\end{array}$ \\
\hline 6 & Pemerintah & $\begin{array}{l}\text { BI, Otoritas, Aturan, Hukum, Ojk, Regulasi, Kebijakan, } \\
\text { Lembaga, Satgas, Peraturan, Legal, Polisi, Kementerian }\end{array}$ \\
\hline 7 & Pasar & $\begin{array}{l}\text { Harga, Produk, Konsumen, Publik, Warga, Market } \\
\text { Facebook, Investor, Ceo, Bisnis, Direktur }\end{array}$ \\
\hline 9 & Kerusahaan & $\begin{array}{l}\text { Data, Aset, Hacker, Pencucian, Ransomware, Malware, } \\
\text { Penipuan, Kejahatan, Ancaman, Peretasan, Terorisme, } \\
\text { Penjahat, Peretas, Password }\end{array}$ \\
\hline 10 & Perbankan & \begin{tabular}{l} 
Atm, Bank, Nasabah, Kurs \\
\hline
\end{tabular} \\
\hline
\end{tabular}

After combining the words with the concept, the next process is counting the code using the atlas.ti tools. The results obtained are as in the following table. 
Table 4. Counting Code Result

\begin{tabular}{|c|l|c|}
\hline No & Concepts & Total Number of Words \\
\hline 1 & Bitcoin & 8887 \\
\hline 2 & Negara & 2098 \\
\hline 3 & Platform & 3864 \\
\hline 4 & Nilai & 3487 \\
\hline 5 & Ekonomi & 5539 \\
\hline 6 & Pemerintah & 1663 \\
\hline 7 & Pasar & 1327 \\
\hline 8 & Perusahaan & 1425 \\
\hline 9 & Keamanan & 1402 \\
\hline 10 & Perbankan & 912 \\
\hline
\end{tabular}

Furthermore, from the results of the counting code, the bivariate connection test will be calculated. This correlation test becomes the basis for making a network connection. The correlation test method used is the Pearson correlation test with a concept based on the level of significance, the smaller the level of significance, the stronger the relationship between these concepts. This is based on the hypothesis used by looking at Ho and $\mathrm{Hi}$. The calculation of the correlation test can be seen in the image below.

\begin{tabular}{|c|c|c|c|c|c|c|c|c|c|c|c|}
\hline \multicolumn{12}{|c|}{ Correlations } \\
\hline & & BITCOIN & EKONOMI & KEAMANAN & NEGARA & NILAI & PASAR & PEMERINTAH & PERBANKAN & $\begin{array}{l}\text { PERUSAHAA } \\
\text { N }\end{array}$ & PLATFORM \\
\hline \multirow[t]{3}{*}{ BITCOIN } & Pearson Correlation & 1 & $.353^{\prime \prime}$ & $\begin{array}{r}-007 \\
\end{array}$ & $.155^{\prime \prime}$ & $.355^{\prime \prime}$ & $.340^{\prime \prime}$ & $\begin{array}{r}.008 \\
\end{array}$ & .063 & $124^{\prime \prime}$ & $.198^{\prime \prime}$ \\
\hline & Sig. (2-tailed) & & .000 & .867 & .000 & .000 & .000 & .847 & 110 & .002 & .000 \\
\hline & $\mathrm{N}$ & 651 & 651 & 651 & 651 & 651 & 651 & 651 & 651 & 651 & 651 \\
\hline \multirow[t]{3}{*}{ EKONOMI } & Pearson Correlation & $.353^{\prime \prime}$ & 1 & $.089^{\circ}$ & $.392^{\prime \prime}$ & .064 & $.142^{\prime \prime}$ & $.438^{\prime \prime}$ & $.363^{\prime \prime}$ & $.125^{\circ}$ & $.475^{\circ}$ \\
\hline & Sig. (2-tailed) & .000 & & .023 & .000 & .104 & .000 & .000 & .000 & .001 & .000 \\
\hline & $\mathrm{N}$ & 651 & 651 & 651 & 651 & 651 & 651 & 651 & 651 & 651 & 651 \\
\hline \multirow[t]{3}{*}{ KEAMANAN } & Pearson Correlation & .007 & $.089^{\circ}$ & 1 & $.108^{\prime \prime}$ & .054 & .031 &,- 001 & .020 & $.089^{\circ}$ & $.353^{2 \pi}$ \\
\hline & Sig. (2-tailed) & .867 & .023 & & .006 & .172 & .433 & .978 & .614 & .024 & .000 \\
\hline & $\mathrm{N}$ & 651 & 651 & 651 & 651 & 651 & 651 & 651 & 651 & 651 & 651 \\
\hline \multirow[t]{3}{*}{ NEGARA } & Pearson Correlation & $.155^{\circ}$ & $.392^{\prime \prime}$ & $.108^{\prime \prime}$ & 1 & $-.078^{\circ}$ & .002 & $.477^{\prime \prime}$ & $.291 "$ & .073 & $.327^{\prime \prime}$ \\
\hline & Sig. (2-taileđ) & .000 & .000 & .006 & & .047 & .957 & .000 & .000 & .061 & .000 \\
\hline & $\mathrm{N}$ & 651 & 651 & 651 & 651 & 651 & 651 & 651 & 651 & 651 & 651 \\
\hline \multirow[t]{3}{*}{ NILAI } & Pearson Correlation & $.355^{\prime \prime}$ & .064 & .054 & $-.078^{\circ}$ & 1 & $.297^{\prime \prime}$ & -.065 & .007 & -.036 & -.020 \\
\hline & Sig. (2-tailed) & .000 & 104 & .172 & .047 & & .000 & .100 & 853 & .362 & .606 \\
\hline & $\mathrm{N}$ & 651 & 651 & 651 & 651 & 651 & 651 & 651 & 651 & 651 & 651 \\
\hline \multirow[t]{3}{*}{ PASAR } & Pearson Correlation & $.340^{\prime \prime}$ & $.142^{\prime \prime}$ & .031 & .002 & $.297^{\prime \prime}$ & 1 & .057 & .029 & $.100^{\circ}$ & .046 \\
\hline & Sig. (2-tailed) & .000 & .000 & .433 & .957 & .000 & & .146 & 457 & .011 & .240 \\
\hline & $\mathrm{N}$ & 651 & 651 & 651 & 651 & 651 & 651 & 651 & 651 & 651 & 651 \\
\hline \multirow[t]{3}{*}{ PEMERINTAH } & Pearson Correlation & .008 & $.438^{\prime \prime}$ & -001 & $.477^{\prime \prime}$ & .065 & .057 & 1 & $.264^{\prime \prime}$ & .066 & $.130^{\circ \prime}$ \\
\hline & Sig. (2-tailed) & 847 & .000 & .978 & .000 & .100 & .146 & & .000 & .090 & .001 \\
\hline & $\mathrm{N}$ & 651 & 651 & 651 & 651 & 651 & 651 & 651 & 651 & 651 & 651 \\
\hline \multirow[t]{3}{*}{ PERBANKAN } & Pearson Correlation & .063 & $.363^{\prime \prime}$ & .020 & $.291^{\circ}$ & .007 & .029 & $.264^{\prime \prime}$ & 1 & .071 & $.147^{\prime \prime}$ \\
\hline & Sig. (2-taileđ) & 110 & .000 & .614 & .000 & .853 & .457 & .000 & & .071 & .000 \\
\hline & $\mathrm{N}$ & 651 & 651 & 651 & 651 & 651 & 651 & 651 & 651 & 651 & 651 \\
\hline \multirow[t]{3}{*}{ PERUSAHAAN } & Pearson Correlation & $.124^{\prime \prime}$ & $.125^{\circ}$ & $.089^{\circ}$ & .073 & .036 & $.100^{\circ}$ & .066 & 071 & 1 & $.158^{\prime \prime}$ \\
\hline & Sig. (2-tailed) & .002 & .001 & .024 & .061 & .362 & .011 & .090 & .071 & & .000 \\
\hline & $\mathrm{N}$ & 651 & 651 & 651 & 651 & 651 & 651 & 651 & 651 & 651 & 651 \\
\hline \multirow[t]{3}{*}{ PLATFORM } & Pearson Correlation & $.198^{\prime \prime}$ & $.475^{\circ}$ & $.353^{\prime \prime}$ & $.327^{\prime \prime}$ & -.020 & .046 & $.130^{\circ}$ & $.147^{\prime \prime}$ & $.158^{\prime \prime}$ & 1 \\
\hline & Sig. (2-tailed) & .000 & .000 & .000 & .000 & .606 & .240 & .001 & .000 & .000 & \\
\hline & $\mathrm{N}$ & 651 & 651 & 651 & 651 & 651 & 651 & 651 & 651 & 651 & 651 \\
\hline
\end{tabular}

Fig. 3. The Results of the Pearson Bivariate Correlation Test Calculation 
After obtaining the results of the calculation of the Pearson bivariate correlation test, it can be seen the relationship between each concept. This relationship is known based on the level of significance; this is the basis for visualizing the network connection for 10 concepts regarding bitcoin. The depiction of a network connection is presented in Figure 4.

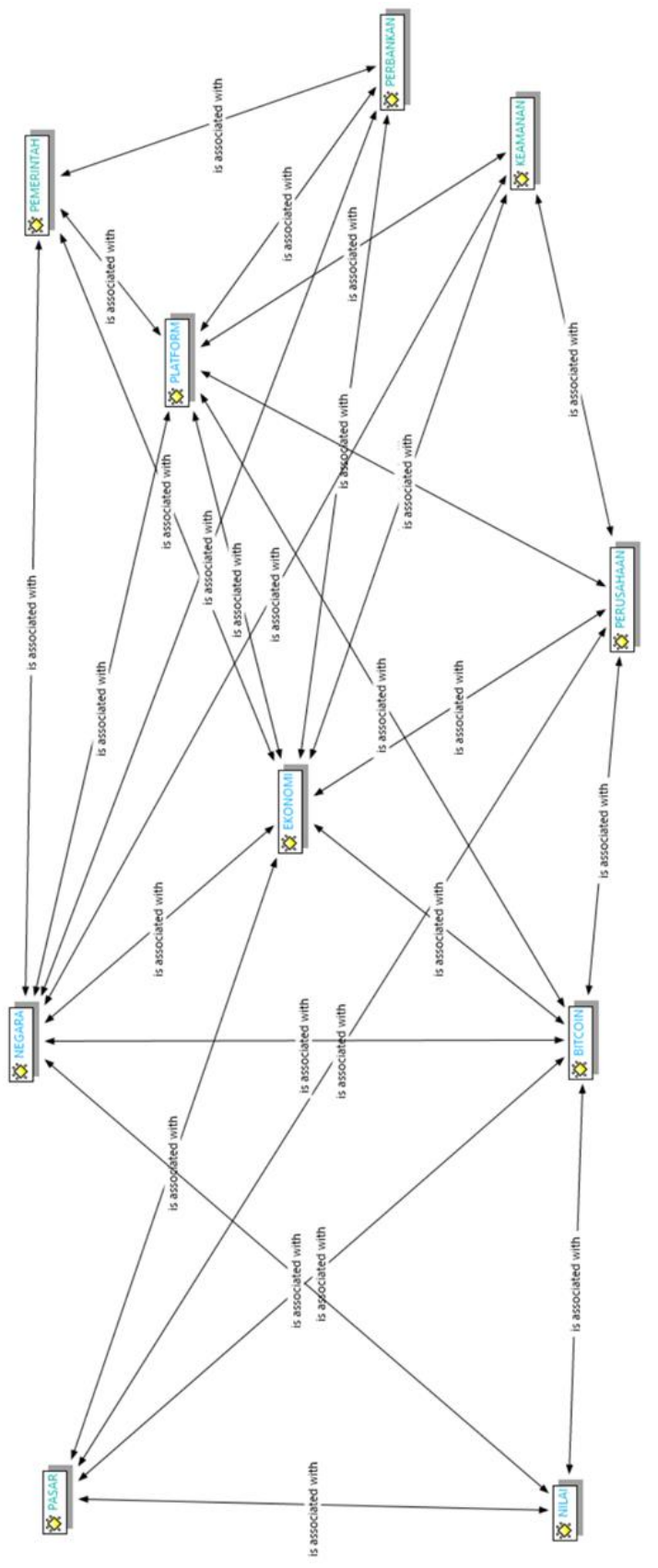

Fig. 4. Network Connection 
The results obtained in this study are that economics is an important point that is prioritized in news about bitcoin. This can be seen in the number connected to the economic concept as many as eight of the nine concepts made. The concept of economic relations with bitcoin can identify that bitcoin is very influential on a person's economy or even a country. The economic concept has links to security, the country, the market, the government, banking, companies and platforms. The economic concept has a relationship with security because security to maintain the stability of a country's economy is an important aspect and security for bitcoin itself, because bitcoin is a digital currency so it is very vulnerable to being infiltrated by malware or even hacked by hackers. The economic concept relates to the concepts of the state, government and banking because it relates to existing regulations to regulate the application of bitcoin and regulate the stability of the circulation of currencies in Indonesia, both digital and conventional. The concept of market and company is related to the economic concept due to the use of bitcoin by the public and companies in investing or just as a means of payment. The concept of the platform has a relationship with the economy because the progress of the world economy is currently very influential on technological developments so that transactions can be carried out online or even using a smartphone and also the platform concept has a relationship with the concept of security to ensure security in terms of information technology in conducting online-based transactions or even using the smartphone.

The economic concept has no connection with the concept of value because the use of digital and conventional currencies is regulated based on the existing exchange rates that have been regulated by the world bank. The concept of security has no relationship with the concept of the market because many Indonesians put aside the security aspect in order to get high profits. The concept of bitcoin has no relationship with the concept of the government illustrating that the use of bitcoin is currently prohibited by the Indonesian government. Currently in big countries such as the United States and Japan, bitcoin is the prima donna. However, it is different from Indonesia, although currently there are regulations that regulate virtual currency issued by the Commodity Futures Trading Supervisory Agency (Bappebti), but the government prohibits the use of bitcoin.

\section{Conclusion}

This research succeeded in formulating 10 important news concepts from online media detik.com, kompas.com, and liputan6.com that have been made. These concepts are bitcoin, country, platform, value, economy, government, market, company, security and banking. The most important concept in this study is the concept of economics, because it is related to eight of the other nine concepts. This illustrates that the progress and use of bitcoin affects some people and even countries. And the absence of a direct connection between the concept of bitcoin and the concept of government illustrates that currently the use of bitcoin in Indonesia is prohibited because it is not supported by the OJK (Financial Services Authority) as a government agency that has a role in maintaining the existence of the rupiah value in society and has not been regulated and has not received guarantee by the central bank or BI (Bank Indonesia) even though currently the Commodity Futures Trading Supervisory Agency (Bappebti) has issued regulations related to virtual currencies. The relationship between these concepts is obtained based on the results of calculations using the Pearson bivariate correlation test method.

\section{References}

Abdul, Syukur Ibrahim, 2009. Metode Analisis Teks \& Wacana, Yogyakarta: Pustaka Pelajar.

Ahmad, Jumal, 2018. Desain Penelitian Analisis Isi (Content Analysis). Jakarta: UIN Syarif Hidayatullah. 
Ayu Erivah Rossy, 2015. Umaimah Wahid. Analisi Isi Kekerasan Seksual Dalam Pemberitaan Media Online Detik.Com, Vol 7, No. 2. Gupta, Raghav, 2017. Journal of Internet Banking and Commerce, vol. 22, no. 3, India.

Kurnia Ekasari, Nurafni Eltivia, Elvyra Handayani Soedarso, 2019. Analisis Konten terhadap Pengungkapan Etika dan Integritas pada Sustainaibility Reporting, Vol 4, No. 1.

Lamria, Suzanna Siregar, 2012. Content analysis and social network analysis for theory building: study on the literature of coopetition. Mulyanto, Ferry, 2015. Pemanfaatan Cryptocurrency Sebagai Penerapan Mata Uang Rupiah Kedalam Bentuk Digital Menggunakan Teknologi Bitcoin. Indonesian Journal of Network security. Vol 7, No 2.

Ouriana, Vitouladiti, 2014. Content Analysis as a Research Tool for Marketing, Management and Development Strategies Tourism. Page 278-287.

Roger D. Wimmer, Joseph R. Dominick, 2000. Mass Media Research: An Introduction, Edisi 6, Wadsworth Pub.

Wouter D. N., Andrej M., Vladimir B, 2005. Exploratory Social Network Analysis With Pajek. Cambridge University. 